\title{
The Research Review of the Impact of Design to Construction Safety
}

\begin{abstract}
The constructability of design impacts the project construction process. Early researches categorized the constructability problems into two types, the construction-technique-associated and the project-target-associated. And furthermore, this paper proposes a new kind of constructability problem which associated with construction safety. Finally, it makes suggestions for research of the safety associated constructability.
\end{abstract}

Keywords: constructability, construction safety, prevention thought design

\section{Introduction}

The gap between design and construction leads to the possibility that the designer and the constructor aim at different targets. For example, a designer may only consider how to enhance the appearance and the functions of a building while the convenience of construction was overlooked. This phenomenon is called "constructability problem", which introduces many troubles into a construction project. Therefore, much research has been concentrated on finding the problems and making suggestions to solve those problems. A key point is to promote the current construction industry. This paper focuses on a type of constructability that relates to construction safety and makes suggestions for its improvement.

Manuscript received June 3, 2015; accepted September 10, 2015

Lin Yang $(\bowtie)$

School of Civil Engineering, Lanzhou Jiaotong University, Lanzhou 730070, China

Email: yanglin5@yeah.net

Qi-ming Li

School of Civil Engineering, Southeast University, Nanjing 210018, China

\section{The definition of constructability}

The Construction Industry Institute (CII) has made a definition for "constructability". Constructability is the optimum use of construction knowledge and experience in planning, design, procurement, and field operation, to achieve overall project objective (Tatum, 1987). If project has some defects of constructability, it is considered a "constructability problem". This paper focuses on constructability in the design and proposes a new kind of problem to review.

\section{The categories of constructability}

Cui and Wang (2007) classified the constructability problems into two categories, the construction technique associated and the project target associated, as are shown in Table 1.

\section{A new kind of constructability problem}

As Table 1 shows, the two categories of constructability problems in design will both impact the cost or schedule of a construction project. To prevent such problems, in the 1990s, some contractors began to perform the "constructability review" for a design before construction (Hinze \& Wiegand, 1992). The literature of Wang and Peng (2003) listed the content of the construction review for a design in China. The substance of these reviews all match the Table 1 description.

This paper proposes that it is not enough to only address the two categories of constructability problems in design, but that there is another category of design problem which also impacts the target of a construction project, as are shown in Table 2. It is the potential for safety problems, which may cause worker injuries or fatalities. If construction accidents happen in a project, the cost increases and the schedule is delayed. So, this category or type of problem must not be ignored. 


\section{The association between design and safety}

Many associations between design and safety including how a design impacts construction safety have been studied by experts.

Driscoll, Harrison, Bradley and Newson (2008) analyzed the data which is in the Australian National Coroners' Information System between 2000 and 2002. The conclusion was that $37 \%$ of the 210 identified workplace fatalities had design-related issues. Smallwood (2008) interviewed many South Africa constructors, $50 \%$ of whom thought a design impacts construction safety. Behm (2005) chose the National Institute for Occupational Safety and Health (NIOSH) Fatality Assessment Control and Evaluation (FACE) program as the source for making an analysis. The result is $42 \%$ of the 224 fatalities were related to design. According to the statistics by U.S. Bureau of Labor Statistics (BLS) (2011), 16.5\% of construction accidents are related to design in U.S. Soeiro, Vasconcelos, and Barkokebas (2014) collected many accident reports, the numbers of which were 675 from the construction company in Brazil, 940 from CCOHS in Canada, 116 from FACE, NIOSH and PtD in U.S., 203 from ACT in Portugal, 100 from HSE in United Kingdom, 41 from WSH Council in Singapore and 32 from SFIT in Brazil. The average ratio of design-relevant accidents in the seven countries is $35.1 \%$. According to the researches above, a conclusion can be deduced. There is some correlation between design and safety, although the methods and criterions for the research is different. Therefore, at the beginning phase of design, certain measures must be performed to reduce the possibility of incidents during construction.

\section{The history of prevention during design}

The idea of prevention during the design phase first appeared in the NSC's 1955 Accident Prevention Manual (National Safety Council, 1955). At that time, this thinking was called "Prevention thought Design" (PtD). The application of PtD in the U.S. construction industry did not occur until the Construction Industry Institute sponsored research Jimmie Hinze and John Gambatese in the 1990s (Gambatese and Hinze, 1997). The PtD concept has been slowly recognized and applied in the U.S. over the past ten years. PtD-related publications and industry interest increased dramatically after a 2003 symposium held at the University of Oregon (Manuele, 2008; Schulte, Rinehart, Okun, Geraci, \& Heidel, 2008). Large designbuilders such as URS, Parsons and Jacobs Engineering have established PtD programs and Kiewit, Fluor, Mustang Engineering and Zachry Engineering have taken steps towards implementing a PtD program. Large owners who have implemented PtD on at least one project include Intel, the Southern Company and Exxon Mobil. Representatives from the U.S. Department of Energy and the U.S. Army Corps of Engineers have also expressed interest in developing a PtD program. OSHA has convened a Design for Construction Safety workgroup composed of approximately ten professional organizations since 2005. The National Institute for Occupational Safety and Health (NIOSH) has recognized PtD as a highly promising safety approach. In 2006, PtD became of one of ten focus areas of the National Occupational Research Agenda (NORA) Construction Sector Council. In 2007 and 2011, NIOSH convened PtD workshops with several hundred participants from eight industry sectors

\section{The solution for the constructability problem of the third kind}

It is necessary to perform a "review for construction safety" before starting construction. The review includes inspection according to safety codes. Furthermore, there are some things which should be considered in the review, such as

Table 1

Constructability Problems in Design

\begin{tabular}{lll}
\hline Category & Description & Example \\
\hline The first category & $\begin{array}{l}\text { In a design, there are some things that may impact the } \\
\text { construction operations. In other words, the design is too } \\
\text { difficult to accomplish }\end{array}$ & $\begin{array}{l}\text { Too many types of rebar and cement. } \\
\text { Bars were too dense to pour concrete. } \\
\text { The section size of beams and columns }\end{array}$
\end{tabular}

The second category In a design, there are some things that may impact the target of a construction project such as schedule or cost

During design for fabricated structure, the column grid is too dense to precast elements between the columns

Table 2

Constructability Problems in Design about Safety

\begin{tabular}{lll}
\hline Category & Description & Example \\
\hline The third category & $\begin{array}{l}\text { In a design, there are some things that may } \\
\text { lead to construction worker injuries. }\end{array}$ & $\begin{array}{l}\text { Too much equipment stored on a high-rise building's roof while a worker is } \\
\text { working may cause injury or death }\end{array}$ \\
\hline
\end{tabular}


previous experiences and using them to predict future incidents in project construction.

For example, current safety codes do not limit where equipment such as central air-conditioning systems are placed, but inconsideration of falling from the roof during installing or repairing it, the equipments should be placed on the ground as much as possible. If some equipment like ventilation system cannot be set on the ground, it is much safer to place the equipment at the center of a roof and keep a safe distance from edge of roof. Furthermore (see Figure 1), it is important to set a guardrail around the work area. If possible, some anchors should be set on the roof for safety ropes (see Figure 2).

\section{The review of current research for safety in design}

Since the 1990s, there has been much research about the topic of developing a knowledge system for PtD. Zeng, Yuan, and Zhang (2014) sum up some main research results as was listed in Table 3, showing the tracks of study from manual format to digital, and from check list to knowledge.

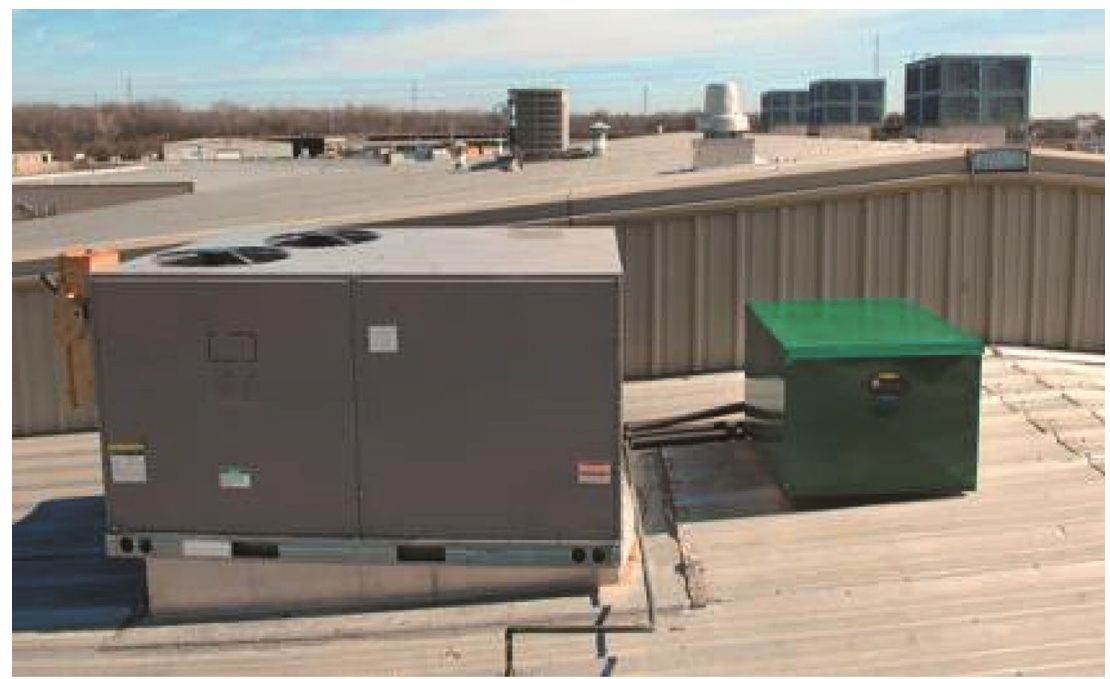

Figure 1. The equipments on the roof.

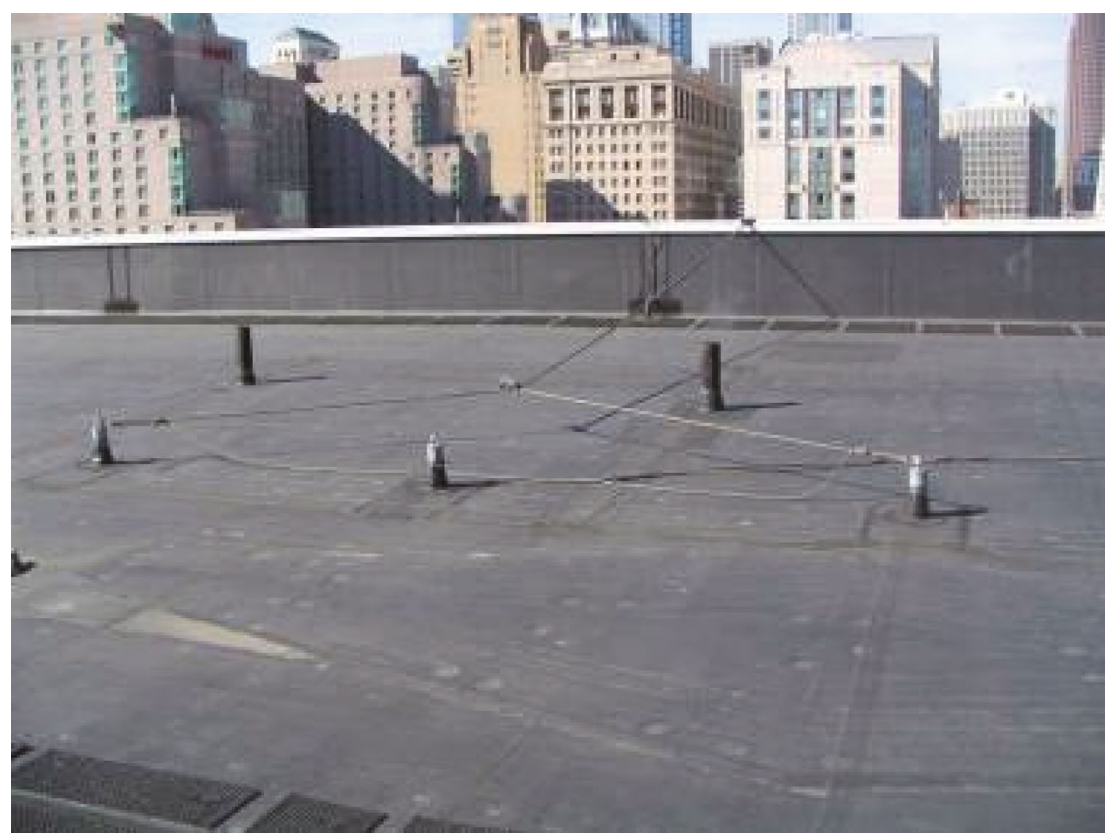

Figure 2. The safety rope anchors on the roof. 
Table 3

The Sum of PtD Methods

\begin{tabular}{|c|c|c|}
\hline Classification & Destination & Methodology \\
\hline $\begin{array}{l}\text { Manual check (Gambatese, Hinze, \& Haas, 1997; Kim, Son, Lee, \& Park, 2006; Zou, } \\
\text { Redman, \& Windon, 2008) }\end{array}$ & Risk identification & Checking list \\
\hline $\begin{array}{l}\text { Analysis by mathematical model (Seo \& Choi, 2008; Cooke, Lingard, Blismas, \& Stranieri, } \\
\text { 2008; Duffy, 2004) }\end{array}$ & Risk assessment & Assessment form \\
\hline Discovery by computer (Reser, 2012) & Design optimization & Computer tool for design review \\
\hline
\end{tabular}

\section{Conclusive remarks}

Safety is a target to continue pursuing. Thus, the concept for safety is developing continually. In the beginning, construction accidents were seen as unavoidable. Overtime, the need for accident prevention has grown. Until recent years, safety science and "system safety" was the target, but was not often put into practice. Slowly, the focuses on safety measures in engineering are begin to move from just the performance phase and into the design phase. It is a positive advancement for safety. This paper suggests that a proper design should eliminate the third kind of constructability problem.

Acknowledgements This research is supported by the National Natural Science Foundation of China (Grant No. 51578144).

\section{References}

Behm, M. (2005). Linking construction fatalities to the design for construction safety concept. Safety Science, 43, 589-611

Bureau of Labor Statistics (2011). Number and rate of fatal occupational injuries, by industry sector. Retrieved from http://www.bls.gov/iif/ oshcfoil.htm

Cooke, T., Lingard, H., Blismas, N., \& Stranieri, A. (2008). ToolSHeDTM: the development and evaluation of a decision support tool for health and safety in construction design. Engineering, Construction, and Architectural Management, 15, 336-351

Cui, Y., \& Wang, X. (2007). Study on constructability of construction project design. Building Construction, 29, 559-561

Driscoll, T.R., Harrison, J.E., Bradley, C., \& Newson, R.S. (2008). The role of design issues in work-related fatal injury in Australia. Journal of Safety Research, 39, 209-214

Duffy, M. (2004). From designer risk assessment to construction method statements: techniques and procedures for effective communication of health and safety information. In: Proceedings of the Designing for Safety and Health in Construction Research and Practice Symposium, 118-135

Gambatese, J. A., \& Hinze, J. W. (1997). A guide for safety inspections. CIB Report, 42-52
Gambatese, J.A., Hinze, J.W., \& Haas, C.T. (1997). Tool to design for construction worker safety. Journal of Architectural Engineering, 3, $32-41$

Hinze, J., \& Wiegand, F. (1992). Role of designers in construction worker safety. Journal of Construction Engineering and Management, 118, 677-684

Kim, S., Son, C., Lee, D., \& Park, C. (2006). Safety assessment checklist during building design phase. In: Fang D., ed. Proceedings of CIB W99 International Conference on Global Unity for Safety and Health in Construction, Beijing, China. 258-264

Manuele, F.A. (2008). Prevention through design (PtD): history and future. Journal of Safety Research, 39, 127-130

National Safety Council. (1955). Accident Prevention Manual for Industrial Operations. Chicago: National Safety Council

Reser, K.A. (2012). Safety in Design Supplement to A Constructability Program (Doctoral dissertation). Ames: Iowa State University

Schulte, P.A., Rinehart, R., Okun, A., Geraci, C.L., \& Heidel, D.S. (2008). National prevention through design (PtD) initiative. Journal of Safety Research, 39, 115-121

Seo, J.W., \& Choi, H.H. (2008). Risk-based safety impact assessment methodology for underground construction projects in Korea. Journal of Construction Engineering and Management, 134, 72-81

Smallwood, J. (2008). The influence of architectural designers on construction ergonomics. Ergonomics SA: Journal of the Ergonomics Society of South Africa, 20, 40-55

Soeiro, A., Vasconcelos, B., \& Barkokebas, B. (2014). Prevention guide for designers based on analysis of about 2000 accidents. (No location): CIB W99

Tatum, C.B. (1987). Improving constructability during conceptual planning. Journal of Construction Engineering and Management, 113, 191-207

Wang, M., \& Peng, F. (2003). How to do the constructability audit in project design stage. Construction Technology, 32, 53-55

Zeng, W., Yuan, J., \& Zhang, X. (2014). Research of DfS rules utilization based on building information modeling. Journal of Information Technology in Civil Engineering and Architecture, 6, 18-23

Zou, P.X., Redman, S., \& Windon, S. (2008). Case studies on risk and opportunity at design stage of building projects in Australia: focus on safety. Architectural Engineering and Design Management, 4, 221238 